\title{
Adolescence and Health Risk Factors
}

\author{
Alba Cortes Alfaro ${ }^{1 *}$ and Damarys Chacón O'farrill² \\ ${ }^{1}$ Specialist of Second Degree in School Hygiene, Master in Epidemiology, Researcher and Assistant Professor, National Institute of Hygiene, Epidemiology \\ and Microbiology, Cuba
}

${ }^{2}$ First Degree Specialist in Gynecology, Second Degree Specialist in General Integral Medicine, Master in Integral Attention to the Woman, Assistant Professor Luis Augusto Turcios Lima Polyclinic, Cuba

Submission: August 08, 2021; Published: August 17, 2021

*Corresponding author: Alba Cortes Alfaro, Specialist of Second Degree in School Hygiene, Master in Epidemiology, Researcher and Assistant Professor, National Institute of Hygiene, Epidemiology and Microbiology, Cuba

Keywords: Adolescence; Health risk factors; Reproductive capacity; Sexual organs; Genetic; Sociocultural; Human resources; Psychological identity; Sexual identity; HIV; Psychoactive substances; Sexual abuse; Sexually transmitted infections; Lesbian; Gay; Transgender; Bisexual -LGBT; AIDS

\section{Adolescence}

Adolescence is a well-defined stage of the human life cycle that lies between childhood and adulthood characterized by profound biological, psychological and social changes, puberty is the biological component of adolescence, referring to morphological and physiological changes that occur in the child until the achievement of the maturation of the sexual organs and reproductive capacity. Worldwide, adolescents only have in common age, since the changes that occur in it are determined by different factors: genetic, sociocultural, economic and environmental, among others [1]. The World Health Organization (WHO) defines adolescence as the period of human growth and development that occurs after childhood and before adulthood, between the ages of 10 and19 [2]. Adolescents account for approximately one sixth of the world's population (1200 million people) [3].

\section{Health Risks}

Although adolescence is considered one of the healthiest stages of life and therefore needs to prepare them to be able to develop their potential, these criteria have generated a certain degree of abandonment in the care of healthy adolescents, as well as adequate training and training of the human resources provided by health services. Although it is still true, the aforementioned can also be considered as one of the most complex and perhaps problematic stages for others, as it constitutes a stage of vulnerability and exposure to risky behaviors which can be found on their own or concur and bring consequences for health. It is a stage of discovery of one's identity (psychological identity, sexual identity...) as well as that of individual autonomy, it is essentially a time of change [4].

Possibly the most important advance related to adolescent health problems is the recognition that behavior plays a major role in health because risky behaviors are important factors in illness, disability, and death.

The fundamental characteristic of risky behaviors is the marked interrelationship between them and can coincide in the same adolescent the known risk behaviors and be present two or three inclusive all such as smoking ingesting psychoactive substances, having or causing an accident, acquiring or spreading a sexually transmitted infection including HIV, committing crimes being mistreated such as using violence, attempting against your life or committing suicide. Adolescents present a greater vulnerability to psychological problems hence depression is the main cause affecting $5 \%$ of this age group to predominate the female sex [5]. At this stage of adolescence, different attitudes are assumed in relation to psychological, physiological, sociocultural and biological aspects; independence is acquired; family detachment is achieved and some behaviors are generated that negatively affect the family and social environment, which can become sources of stress and unhealthy lifestyles.

Leal 6 in his study considered another aspect to be taken into account in the risks, during this stage referring to the theories that would explain the association between the age of menarquía and 
risk behaviors, referring to the pubertal development that occurs during the initial adolescence (10 to 13 years), characterized by rapid physical changes, which would lead to an inadequate selfperception, associated with the impulse of experimentation and search for identity, where the pairs take great importance.

In this study conducted in Chile, [6] conducted with the aim of determining the association between the age of menarche and presence of risky behaviors in adolescents, it was found that the history of sexual abuse had occurred in $25.47 \%$ in the group that had early menarche and in $21.42 \%$ in adolescents with non-early menarche as well as in terms of risk behaviors, the median age of onset of tobacco, alcohol and drug consumption was lower in adolescents with early menarche and a median for the initiation of sexual relations was 15 years for both groups.

In the initial stage of adolescence, sexuality, in all its bodily and emotional dimension, will have a primary role. There is little doubt that, in this age, the experience and expression of sexuality will be one of the most momentous issues. During the teenage years, the psychic constitution of sexual identity and loving choice will be at stake [7]. Another aspect to highlight are the behaviors of sexual or social risks and the combination of both are very dangerous for sexual and reproductive health so that adolescence is considered a vulnerable group [8]. The main consequence of risky sexual behavior is framed in reproductive damage with the presence of the increase in early pregnancies, abortions and sexually transmitted infections (STIs) including HIV, which in turn if related to risky social behaviors can unfortunately culminate in the frustration of the life project [9].

As the risk of sexually transmitted infections increases due to constant changes of partner, the consumption of toxic substances and the limited use of preventive methods, the lack of knowledge about the infection and the insufficient perception of the risk of contracting it, inappropriate beliefs are often formed about the different objects and phenomena of reality and inappropriate attitudes towards these phenomena are also exhibited. It is also a stage that they tend not to assess the danger, which leads them to suffer accidents, to consume alcohol, cigars or illicit drugs in others present difficulties in school or communication problems with their parents within the home.

At this stage there are mental changes that occur such as those related to the mood that if not having an adequate management of the environment that surrounds it, can lead to a depressive state that among other factors that influence it constitutes not having an adequate atmosphere for its development: loneliness, lack of family communication, early marriages, delinquency, bullying, drug addiction, discrimination, abuse against lesbian, gay, transgender, bisexual -LGBT community among others, which makes them a public health problem, both in industrialized and developing countries.

The burden of individual pressures or responsibilities, together with inexperience and immaturity, lead to the generating of stumbles that can result in moments of anguish, loneliness and frustration, which lead to risk factors for committing a suicidal act or behavior. Other risk factors are school difficulties that are predictors of suicidal ideations and behaviors at this stage of life. Other events that make them vulnerable to these behaviors are: the direct threat to their self-image or dignity; the separation of friends, classmates, boyfriends and girlfriends; the death of a loved one or other significant person; interpersonal conflicts or loss of valuable relationships; disciplinary problems in school or legal situations for which the adolescent must respond, the high demand of parents and teachers during the examination period; unwanted pregnancy, sexually transmitted infections; suffering from a serious physical illness, being subjected to death threats or beatings; be the subject of ridicule at school; failure to comply with the expectations placed by the parents, among others constitute risk factors for committing such behaviors [10].

It is important to note that the World Health Organization (WHO) in its report "Health for the World's Adolescence" called for greater attention to be paid to adolescent health because of the inclusion of road injuries, HIV/AIDS and suicide as the main causes of death and because depression is the leading cause of illness and disability in this population group [4].

\section{Final Considerations}

It is put in the hands of the personnel linked to the work with adolescents including parents and guardians or other personnel linked to the work with them, this small article related to the risk factors that may be present in the adolescents which will allow to be in the best conditions to detect them and contribute to a better control.

\section{References}

1. Cruz Sánchez F (2016) Adolescence. ECIMED, Havana, Cuba.

2. WHO (2016) Development in adolescence. World Health Organization, Geneva, Switzerland.

3. WHO (2018) Adolescents: Health Risk and Solutions.

4. WHO (2014) WHO calls for greater attention to adolescent health.

5. (2016) What are the main health problems of adolescence. Infohealth.

6. Leal FI, Valeria SA, Temístocles MG, Electra González (2015) Early menarche and its association with risky behaviors in adolescents. Revista chilena de obstetricia y ginecología 80(1).

7. WHO (2018) Adolescents: health risks and solutions.

8. Guerrero N, Pérez M (2016) Integral Education of sexuality in childhood, adolescence and youth. Conceptual approach: reflections and views on sexuality in childhood, adolescence and youth. CENESEX, Havana, Cuba, p. 21.

9. Morales OR (2015) Universal health coverage. Cuban experience.

10. Alba Cortés Alfaro, Minervina Román Hernández Ramón Suárez Medina, Rosa María Alonso Uría (2021) Suicidal behavior, adolescence and risk. Revista Anales de la Ciencia de la Academia de ciencias de Cuba 11(2). 
CC Commons Attribution 4.0 License DOI: 10.19080/JGWH.2021.21.556079
DO

\section{Your next submission with Juniper Publishers will reach you the below assets}

- Quality Editorial service

- Swift Peer Review

- Reprints availability

- E-prints Service

- Manuscript Podcast for convenient understanding

- Global attainment for your research

- Manuscript accessibility in different formats

( Pdf, E-pub, Full Tsext, Audio)

- Unceasing customer service

Track the below URL for one-step submission

https://juniperpublishers.com/online-submission.php 